Bureaucratic Intimacies 
Stanford Studies in Middle Eastern and Islamic Societies and Cultures 


\section{Bureaucratic Intimacies}

TRANSLATING HUMAN RIGHTS IN TURKEY

Elif M. Babül 
Stanford University Press

Stanford, California

(92017 by the Board of Trustees of the Leland Stanford Junior University. All rights reserved.

No part of this book may be reproduced or transmitted in any form or by any means, electronic or mechanical, including photocopying and recording, or in any information storage or retrieval system without the prior written permission of Stanford University Press.

Printed in the United States of America on acid-free, archival-quality paper

Library of Congress Cataloging-in-Publication Data

Names: Babül, Elif M., author.

Title: Bureaucratic intimacies : translating human rights in Turkey / Elif M. Babül.

Description: Stanford, California : Stanford University Press, 2017. | Series: Stanford studies in Middle Eastern and Islamic societies and cultures | Includes bibliographical references and index.

Identifiers: LCCN 2017020873 (print) | LCCN 2017022258 (ebook) | ISBN 9781503603394 (e-book) | ISBN 9781503601895 (cloth : alk. paper) | ISBN 9781503603172 (pbk : alk. paper)

Subjects: LCSH: Human rights--Turkey. | Human rights--Study and teaching--Turkey. | Turkey--Officials and employees--Training of. |

European Union--Turkey.

Classification: LCC JC599.T9 (ebook) | LCC JC599.T9 B33 2017 (print) | DDC 323.09561--dc23

LC record available at https://lccn.loc.gov/2017020873

Cover design: Angela Moody

Cover image: Gökhan Deniz, "Hasat Mevsimi" (Harvest Time) Series, 2009.

Typeset by Bruce Lundquist in 10/14 Minion Pro 